\title{
Stomatitis aftosa rekuren oleh karena anemia
}

\author{
*Maharani Laillyza Apriasari, **Hening Tuti \\ * Peserta PPDGS Ilmu Penyakit Mulut \\ ** Bagian Ilmu Penyakit Mulut \\ Fakultas Kedokteran Gigi Universitas Airlangga \\ Surabaya, Indonesia
}

\begin{abstract}
Recurrent aphthous stomatitis (RAS) is the common lesion in oral cavity. The etiology of RAS remains unclear. The trigger factors are genetic, traumatic, abnormal immunology, digestive diseases, hormonal disturbance, HIV, stress, infection and nutrition deficiency. This is a case report of a patient with minor, multiple, pain, white color ulcer with erythema halo on lips palatum and tongue mucous. One day before the ulcers erupted, prodromal symptoms had occurred such as subfebris, malaise, and dizziness. The patient was 19-year-old, male, undergraduate student and with history of ulceration every month. The clinical diagnosis was primary herpetic gingivostomatitis. The differential diagnosis was RAS. The complete blood count $(C B C)$ result indicated that the patient suffered anemia. He was provided with benzydamin $\mathrm{HCl}$ gargle and oral supplement contain ferrous, vitamins, and minerals. It can be concluded that anemia can be a trigger factor of RAS. Therefore, it is important for the dentist to know the clinical signs and manifestations of anemia in oral cavity in order to provide an appropriate treatment.
\end{abstract}

Key words: reccurent aphthous stomatitis, anemia

\begin{abstract}
ABSTRAK
Stomatitis aftosa rekuren (SAR) adalah lesi yang paling sering muncul dalam rongga mulut. Etiologi SAR belum diketahui dengan jelas, diduga karena adanya faktor pemicu seperti genetik, trauma, imunologi yang abnormal, penyakit saluran pencernaan, hormonal, HIV, stres, infeksi, dan defisiensi nutrisi. Pada kasus ini dilaporkan pasien dengan ulser minor, multipel, sakit, warna putih di kelilingi kemerahan pada mukosa bibir bawah dan atas, palatum, serta lidah. Sehari sebelum ulser muncul, ada gejala prodromal berupa demam, lemah, lesu, dan pusing. Pasien berusia 19 tahun, laki-laki, mahasiswa dan memiliki riwayat sariawan hampir tiap bulan. Diagnosis klinisnya adalah stomatitis herpetika primer Diagnosis bandingnya adalah SAR. Hasil pemeriksaan darah lengkap sebagai pemeriksaan penunjang menunjukkan diagnosis akhir pasien adalah menderita anemia. Terapi yang diberikan adalah obat kumur benzydamin $\mathrm{HCl}$ dan secara oral suplemen yang berisi zat besi, vitamin dan mineral. Disimpulkan bahwa anemia dapat menjadi faktor pencetus timbulnya SAR. Dengan demikian penting bagi dokter gigi untuk mengetahui gejala klinis dan kelainan akibat anemia dalam mulut, sehingga dokter gigi dapat memberikan terapi dengan tepat.
\end{abstract}

Key words: reccurent aphthous stomatitis, anemia

Korespondensi: Maharani Laillyza Apriasari, Peserta Program Pendidikan Dokter Gigi Spesialis Ilmu Penyakit Mulut Fakultas Kedokteran Gigi Universitas Airlangga, Jl. Prof. Dr. Moestopo 47 Surabaya, Indonesia. E-mail: rany_rakey@yahoo.com, Hp: 081703521321. 


\section{PENDAHULUAN}

Recurrent aphthous stomatitis (RAS) adalah ulserasi pada rongga mulut yang menimbulkan rasa sakit, dan terjadi pada interval waktu beberapa hari atau lebih dari 2-3 bulan. ${ }^{1,2}$ RAS paling sering muncul di rongga mulut, terjadi $20 \%$ dari populasi dan $2 \%$ diantaranya merasa sangat menderita. ${ }^{2-4}$ Jumlah wanita yang menderita RAS lebih banyak daripada laki-laki, dan lebih sering terjadi pada usia dekade kedua dan tiga. ${ }^{1}$

Manifestasi klinis dari RAS adalah ulser, tunggal atau multipel, dangkal, bulat lonjong, dan sakit. Tipe RAS ada tiga macam, yaitu RAS minor, RAS mayor, dan jenis herpetiform. ${ }^{2}$ Gejala prodromal muncul sebelum timbulnya RAS meliputi rasa yang tidak nyaman dan kemerahan selama 1-3 hari. Kemudian segera diikuti ulser pada rongga mulut yang terasa sakit. Lesi terjadi pada mukosa mulut pada bagian yang berkeratin ataupun seperti pada mukosa bukal, mukosa labial, lidah, dasar mulut, palatum lunak, dan uvula. $^{1}$

Etiologi RAS belum diketahui dengan jelas. Diduga karena adanya faktor pemicu seperti genetik, trauma, imunologi yang abnormal, penyakit saluran pencernaan, hormonal, HIV, stres, infeksi, dan defisiensi nutrisi. ${ }^{1-3,5}$ Kekurangan zat besi, asam folat, dan vitamin B12 dilaporkan terjadi pada lebih dari $20 \%$ pasien yang menderita RAS. $^{2,3}$ Anemia karena kekurangan zat besi adalah prevalensi tertinggi dari semua jenis anemia. ${ }^{6}$

Zat besi, asam folat, dan vitamin B12 sangat penting untuk proses eritropoisis. Sel darah merah dalam sirkulasi darah tubuh, mengangkut oksigen ke jaringan bersama haemoglobin yang didapat dari zat besi berada di dalamnya. Sel darah merah yang normal berbentuk bikonkaf, kecuali jika terjadi gangguan maka sel darah merah menjadi tidak beraturan dalam bentuk dan ukuran. Hal ini menunjukkan tidak berfungsinya sel darah merah dengan baik. Pembentukan sel darah merah dalam sumsum tulang distimulasi beberapa faktor nutrisi, yang paling banyak berasal dari vitamin B12 dan asam folat. ${ }^{2,4}$

Jenis anemia ditentukan dari pemeriksaan darah lengkap, yaitu berdasarkan nilai mean corpuscular volume (MCV) adalah volume sel darah merah rata-rata, mean corpuscular haemoglobine $(\mathrm{MCH})$ adalah kandungan hemoglobin eritrosit, dan mean corpuscular haemoglobine concentration (MCHC) adalah konsentrasi hemoglobin dalam eritrosit. Sel darah merah normal apabila hasil pemeriksaan darah lengkap menunjukkan MCV antara 80-96 fl, $\mathrm{MCH}$ 28-33pg, MCHC 33-36 g/dl. Klasifikasi anemia berdasarkan patofisiologinya dilihat dari ukuran sel darah merah (mikrositik $\mathrm{MCV}<80 \mathrm{fl}$, normositik MCV antara 80-96 fl, makrositik MCV>96 fl), dan konsentrasi hemoglobin (hipokromik $\mathrm{MCH}<28 \mathrm{pg}$, normokromik $\mathrm{MCH}$ antara $33-36 \mathrm{pg}){ }^{5,7}$

Gejala anemia mulai tampak apabila ada penurunan jumlah hemoglobin normal dalam sirkulasi darah. Penurunan ini terjadi karena ada perdarahan yang menjadi penyebab utama anemia, adanya kerusakan sel darah merah seperti pada anemia hemolitik dan penurunan produksi sel darah merah karena anemia pernisiosa atau menurunnya jumlah asupan zat besi. ${ }^{5}$

Artikel ini melaporkan kasus tentang terjadinya recurrent aphthous stomatitis pada pasien sebagai manifestasi dari anemia. Secara klinis lesi RAS yang muncul berupa lesi ulser minor multipel dan menyebar. Awalnya pasien didiagnosis klinis sebagai stomatitis herpetika primer, karena sehari sebelum muncul lesi diawali gejala prodromal berupa lemas, lesu, dan demam. Hal ini diragukan karena pasien juga memiliki riwayat recurrent aphthous stomatitis hampir tiap 
bulan, kemudian dilakukan pemeriksaan darah lengkap yang hasilnya menunjukkan pasien menderita gejala anemia.

\section{KASUS}

Pasien laki-laki berusia 19 tahun datang ke kamar terima Fakultas Kedokteran Gigi Universitas Airlangga dengan keluhan sariawan pada bibir atas dan bawah, langit-langit (Gambar 1), serta lidah. Sehari sebelum sariawan muncul, pasien merasa lemas, lesu, dan demam. Lalu pasien meminum amoxycillin $500 \mathrm{mg} 3 \times 1$ dan paracetamol $500 \mathrm{mg} 3 \times 1$ selama 3 hari. Demam turun setelah hari kedua meminum obat, tetapi muncul sariawan pada lidah, bibir atas dan bawah serta langit-langit. Sariawan sebanyak ini baru pertama kali diderita pasien. Keadaan umum penderita mudah lelah dan pusing. Pasien memiliki riwayat sering sariawan hampir setiap bulan selama 2 tahun terakhir ini, sering berdebar-debar dan telapak tangannya berkeringat dingin.

\section{TATA LAKSANA KASUS}

Kunjungan I (15 Oktober 2008)

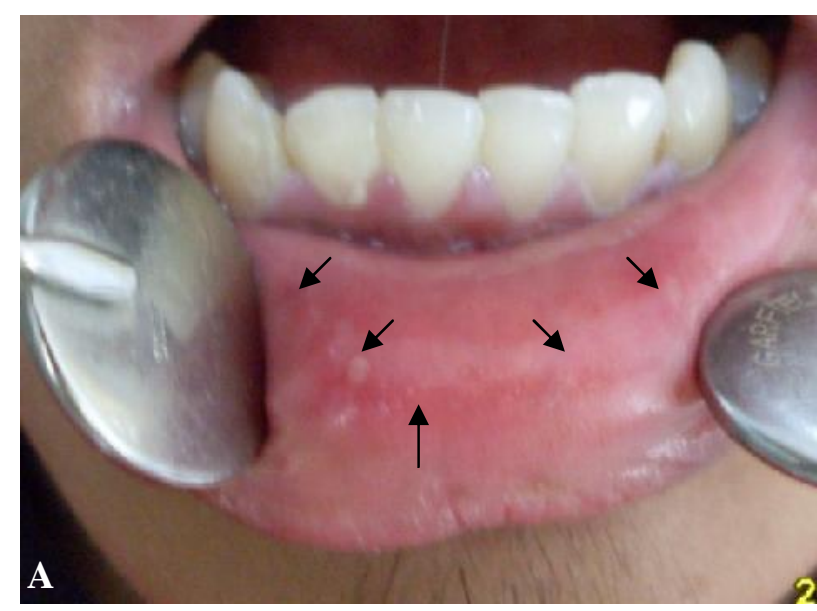

Pada pemeriksaan ekstra oral diketahui kedua kelenjar submandibula, kiri dan kanan teraba, lunak, dan sakit. Pemeriksaan intra oral tampak lesi pada mukosa labial atas dan bawah, lidah, serta palatum berupa ulser, multipel, menyebar, diameter 1-2 mm, sakit, warna putih kekuningan, batas jelas, dikelilingi daerah kemerahan (Gambar 2A). Pada lidah terdapat depapilasi dan kemerahan (Gambar 2B).

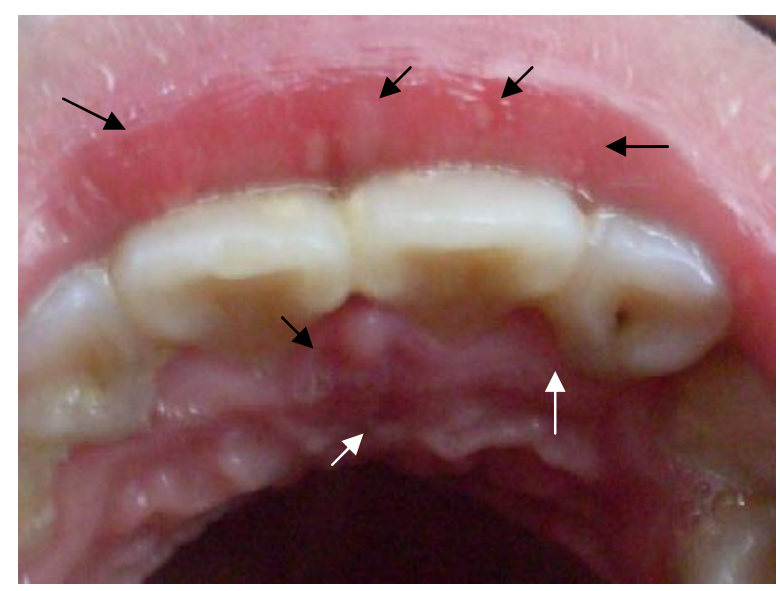

Gambar 1. Gambaran klinis pada kunjungan pertama. Tampak pada bibir atas dan palatum durum terdapat ulser, multipel, menyebar, diameter 1-2 mm, sakit, dan warna putih kekuningan dikelilingi kemerahan.

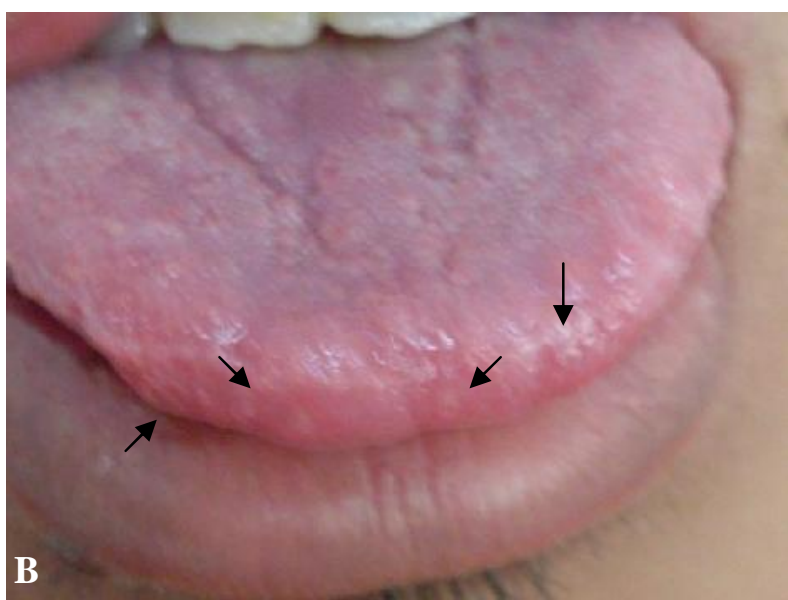

Gambar 2. Gambaran klinis pada kunjungan pertama. A. Pada bibir bawah terdapat ulser, multipel, menyebar, diameter 1-2 mm, sakit, warna putih kekuningan dikelilingi kemerahan. B. Pada lidah terdapat ulser, multipel, menyebar, diameter 1-2 mm, sakit, warna putih, dikelilingi kemerahan serta depapilasi dan kemerahan. 
Awalnya pasien didiagnosis sementara menderita stomatitis herpetika primer, karena sehari sebelum munculnya lesi diawali gejala prodromal berupa lemas, lesu, dan demam. Berdasarkan hasil anamnesis pasien juga memiliki riwayat recurrent aphthous stomatitis hampir tiap bulan, sehingga pasien diminta melakukan pemeriksaan darah lengkap. Terapi yang diberikan adalah obat kumur benzydamin $\mathrm{HCl} 3$ x 1 dan multivitamin yang mengandung vitamin $B$ kompleks dan vitamin $\mathrm{C}$ diminum 1 x 1 . Pasien diminta kontrol 3 hari kemudian.

\section{Kunjungan II ( 17 Oktober 2008)}

Dua hari kemudian pasien datang untuk kontrol pertama. Pasien diminta datang untuk menunjukkan hasil pemeriksaan laboratorium darah lengkapnya, tetapi pemeriksaan darah belum dilakukan. Hasil anamnesis diketahui bahwa rasa sakit pada sariawan berkurang dan pasien sudah bisa makan. Sariawan masih ada pada bibir atas dan bawah (Gambar 3). Pada lidah dan langitlangit sudah sembuh. Keadaan umum pasien masih mudah lelah dan pusing. Multivitamin yang diberikan diminum dengan teratur, demikian juga dengan pemakaian obat kumur benzydamin $\mathrm{HCl}$

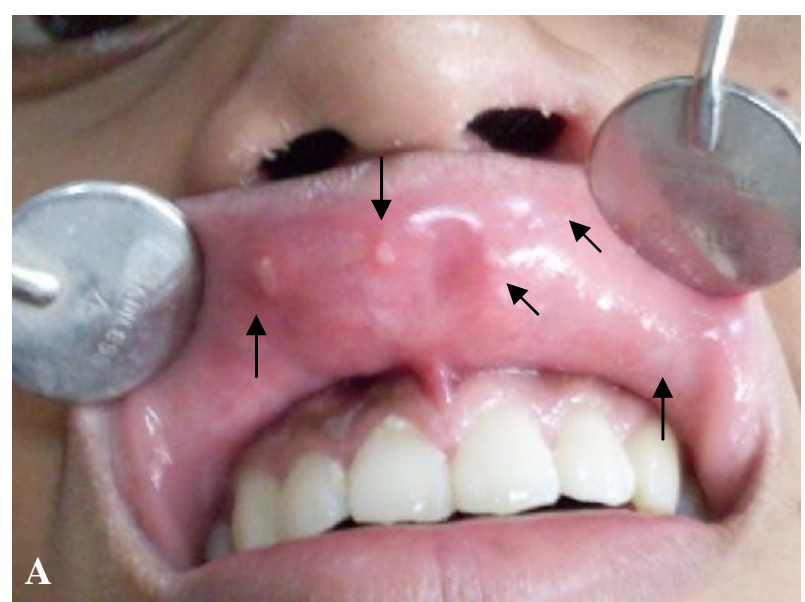

dikumur teratur.

Pemeriksaan ekstra oral menunjukkan tidak ada kelainan. Pemeriksaan intra oral menunjukkan pada mukosa bibir atas dan bawah tampak adanya ulser, multipel, menyebar, diameter 2-4 mm, bulat, warna putih kekuningan, dikelilingi daerah kemerahan, dan tidak sakit. Ulser menjadi lebih besar dari kunjungan sebelumnya, oleh sebab itu pasien disarankan untuk melakukan pemeriksaan darah lengkap.

Pasien diminta meneruskan multivitamin yang masih ada, dan terus berkumur benzydamin $\mathrm{HCl}$ serta mengkonsumsi makanan yang bernutrisi tinggi seperti susu, sayur, dan buahbuahan.

\section{Kunjungan III ( 20 Oktober 2008)}

Anamnesis pada hari kelima, diketahui bahwa sariawan pada bibir atas dan bawah membaik dan tidak sakit. Pasien masih mudah lelah dan pusing. Pemeriksaan darah lengkap sudah dilakukan dan didapat hasil sebagai berikut, yaitu $\mathrm{Hb}$ 12,6 g/dl (normal 14-17,4 g/dl), PCV $36,6 \%$ (normal 42-50\%), MCH 27,9 (normal 28$33 \mathrm{pg}$ ), monosit 10 (normal 3-9\%), LED pada jam II 35 (normal 0-15).

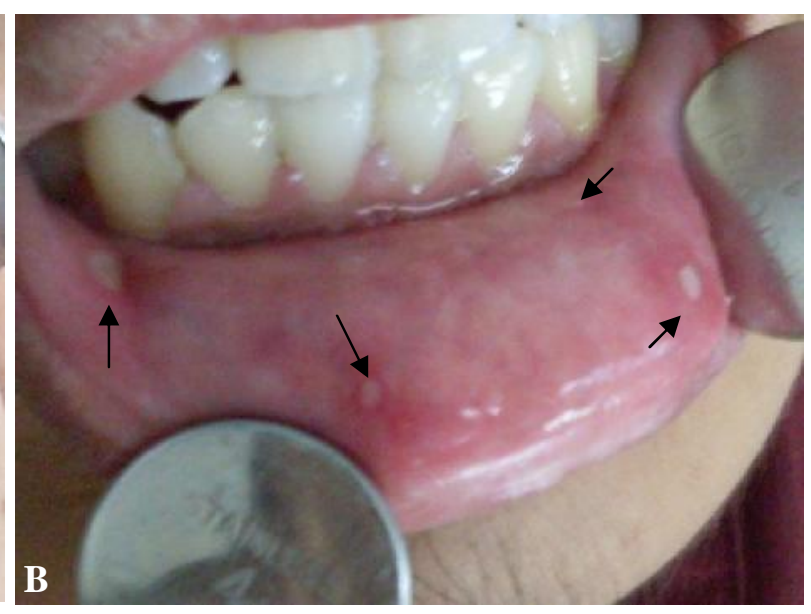

Gambar 3. Gambaran klinis pada kunjungan kedua. A. Pada mukosa bibir bawah terdapat ulser, mutipel, menyebar, diameter 2-4 mm, warna putih kekuningan, dikelilingi kemerahan, tidak sakit. B. Pada mukosa bibir atas terdapat ulser, mutipel, menyebar, diameter 2-4 $\mathrm{mm}$, warna putih kekuningan, dikelilingi kemerahan, dan tidak sakit 
Dari pemeriksaan ekstra oral tidak didapatkan kelainan. Pemeriksaan intra oral menunjukkan bahwa ulser pada mukosa bibir atas dan bawah mengecil, diameter $0,5 \mathrm{~mm}$, multipel, menyebar, warna kekuningan, dikelilingi kemerahan, dan tidak sakit (Gambar 4).

Berdasarkan hasil pemeriksaan darah, pasien didiagnosis akhir menderita recurrent aphthous stomatitis karena anemia, selanjutnya pasien mendapat terapi suplemen yang berisi zat besi, multivitamin dan mineral $2 \times 1$, dan dianjurkan kontrol seminggu kemudian.

\section{Kunjungan IV ( 30 Oktober 2008)}

Kontrol ketiga dilakukan 10 hari kemudian. Pada anamnesis diketahui sariawan sudah sembuh dan hilang. Kondisi pasien semakin membaik. Pasien tidak lagi merasa lemah, mudah lelah, dan pusing.

Pemeriksaan ekstra oral dan intra oral tidak ada kelainan (Gambar 5). Pasien disarankan untuk tetap mengkonsumsi suplemen $1 \times 1$ selama sebulan sebagai terapi maintenance. Apabila sariawan timbul lagi, pasien diminta kontrol kembali.

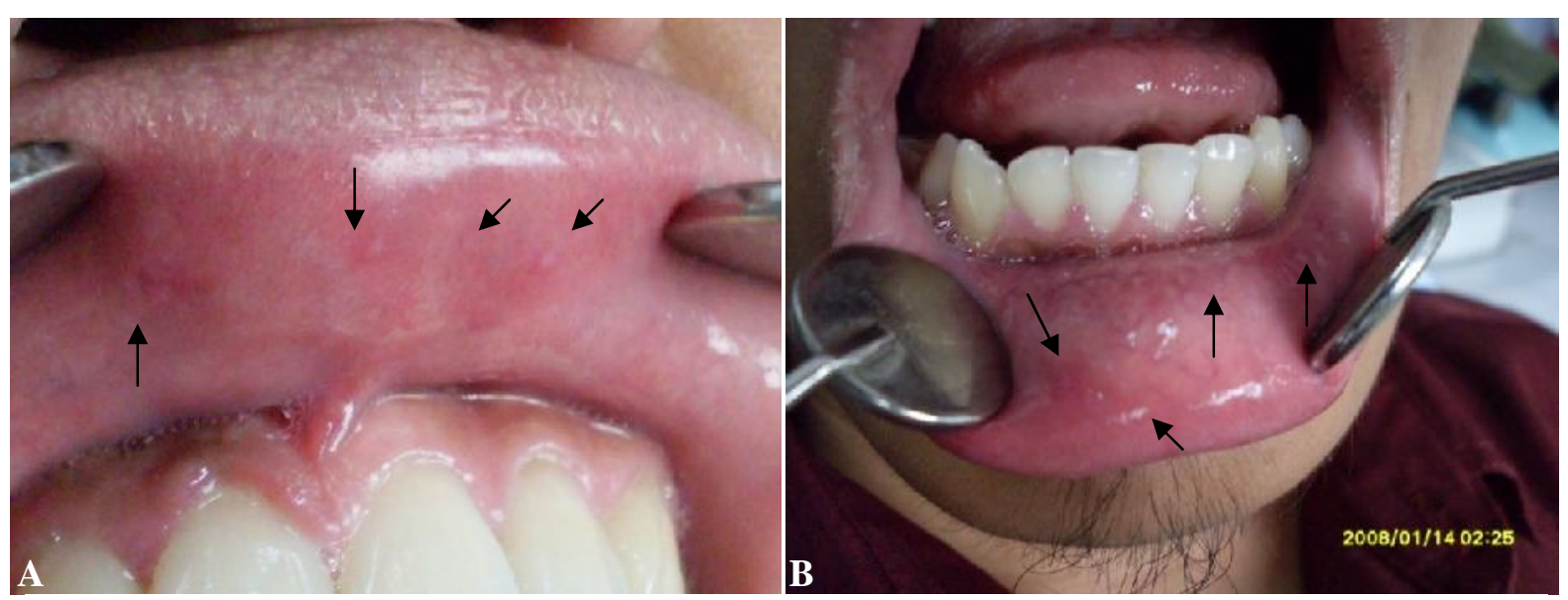

Gambar 4. Gambaran klinis pada kunjungan ketiga. A. Pada mukosa bibir bawah terdapat ulser, mutipel, menyebar, diameter $0,5 \mathrm{~mm}$, warna putih kekuningan, dikelilingi kemerahan, tidak sakit. B. Pada mukosa bibir atas terdapat ulser, mutipel, menyebar, diameter 0,5 mm, warna putih kekuningan, dikelilingi kemerahan, dan tidak sakit.
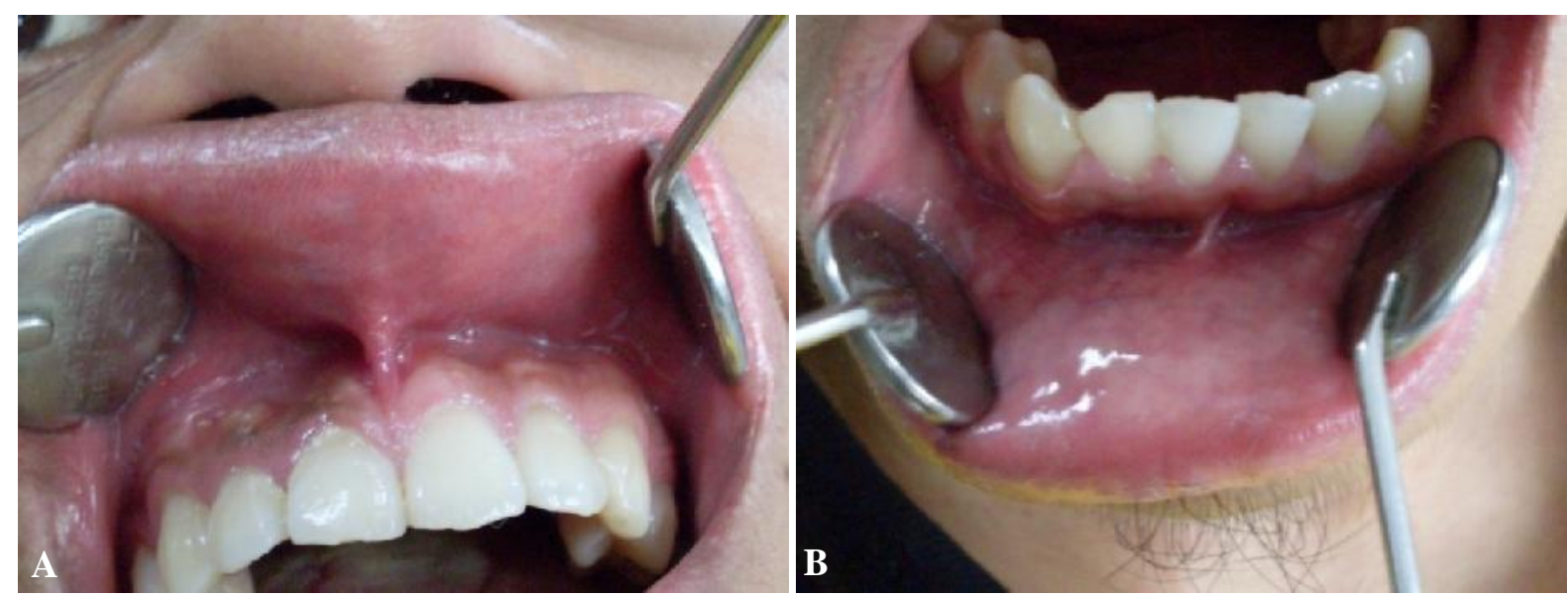

Gambar 5. Gambaran klinis pada kunjungan keempat. A. Pada mukosa bibir atas ulser sudah hilang dan keadaan membaik, B. Kunjungan 4. Pada mukosa bibir bawah ulser sudah hilang dan keadaan membaik 


\section{PEMBAHASAN}

Recurrent aphthous stomatitis merupakan salah satu lesi yang sering terjadi di rongga mulut. Prevalensi pada populasi secara umum berkisar 5$66 \%$. Hipotesis dari terjadinya RAS bermacammacam, tergantung pada faktor pemicunya, antara lain disebabkan karena alergi, faktor genetik, kekurangan nutrisi, kelainan hematologi, hormonal, infeksi, trauma, dan stres. ${ }^{8}$

Pada kasus ini pasien adalah mahasiswa, lakilaki, berusia 19 tahun, bertempat tinggal 'indekos'. Pasien datang dengan ulser, multipel, menyebar, terasa sakit, terletak pada mukosa bibir atas dan bawah, lidah, serta palatum durum anterior. Pada hasil anamnesis pasien memiliki riwayat sariawan hampir tiap bulan sejak 2 tahun lalu. Sehari sebelum muncul ulser pasien mengalami gejala prodromal berupa lemah, lesu, dan demam. Demam menurun setelah dua hari pasien mengkonsumsi amoxycillin $500 \mathrm{mg}$ dan paracetamol $500 \mathrm{mg} 3 \times 1$. Keadaan umum pasien mudah lelah dan pusing.

Semula pasien didiagnosis klinis sebagai stomatitis herpetika primer karena sehari sebelum muncul ulser minor yang multipel, terdapat gejala lemas, lesu dan demam, diikuti ulser minor multipel terletak pada palatum, lidah, mukosa bibir atas dan bawah yang timbul sebanyak ini untuk pertama kali. Diagnosis bandingnya adalah recurrent aphthous stomatitis, karena pasien menderita sariawan hampir tiap bulan, terutama saat pasien sedang banyak kegiatan sehingga makan tidak teratur. Lokasi ulser minor multipel pada rongga mulut menyebar dan tidak bergerombol seperti lesi pada infeksi virus Herpes simpleks pada umumnya. Karena pada saat datang pasien mengeluh pusing dan mudah lelah, jantung berdebar-debar dan telapak tangan berkeringat, yang mirip dengan gejala anemia, maka pasien selanjutnya diminta melakukan pemeriksaan darah lengkap. Hal ini untuk memastikan ada atau tidak gejala anemia pada pasien.

Terapi untuk mengurangi rasa sakit pada ulser dan agar dapat makan dengan baik, maka pasien diberi obat kumur benzydamin $\mathrm{HCl} 3 \times 1$ sehari karena bersifat anastesi topikal. Obat yang diminum adalah multivitamin yang mengandung vitamin B kompleks dan C untuk meningkatkan sistem imun dan mendukung proses penyembuhan. ${ }^{2,5,9}$

Setelah pasien melakukan pemeriksaan darah lengkap didapatkan hasil yaitu $\mathrm{Hb}$ 12,6, PCV $36,6 \%$, dan $\mathrm{MCH}$ 27,9\%. Data tersebut menunjukkan adanya gejala anemia. Pada pemeriksaan darah lengkap pasien, anemia dapat terlihat dari rendahnya hemoglobin $12,6 \mathrm{dl}$ (normal 14-17,4 dl) dan hematokrit/ PCV 36,6\% (normal 42-50\%). ${ }^{10}$ Katagori anemia dari pasien adalah anemia yang hipokromik $(\mathrm{MCH}<28 \%)$ dan normositik (MCV 81,4 antara 80- 96 fl). Pada anemia jenis hipokromik normositik ini terjadi kekurangan zat besi fase laten, yaitu cadangan zat besi dalam tubuh sedikit, sedangkan di dalam sirkulasi darah serum zat besi berkurang dan terjadi penurunan hemoglobin. Pada fase laten ini sering terjadi kelainan di dalam rongga mulut, antara lain berupa glossitis, glossodynia, angular cheilitis, recurrent aphthous stomatitis dan burning mouth. ${ }^{2,7,11}$

Diagnosis gejala anemia lainnya didukung dari adanya gejala klinis pasien seperti mudah lelah dan pusing, serta timbul ulser minor, multipel dan menyebar. Pasien juga mengeluh telapak tangannya selalu berkeringat dan jantungnya sering berdebar-debar. Anemia menyebabkan gangguan transpor oksigen. Jaringan diberi oksigen oleh sel darah merah melalui sirkulasi darah, jadi apabila sel darah merah menurun, hemoglobin menurun, maka terjadi kekurangan oksigen. Anemia yang kronis 
menyebabkan munculnya manifestasi klinis pada pasien seperti mudah lelah, lesu dan palpitasi. ${ }^{2,7}$

Patofisiologi anemia dapat menyebabkan terjadinya RAS, adalah anemia menyebabkan aktivitas enzim-enzim pada mitokondria dalam sel menurun karena terganggunya transpor oksigen dan nutrisi, sehingga menghambat diferensiasi dan pertumbuhan sel epitel. Akibatnya proses diferensiasi terminal sel-sel epitel menuju stratum korneum terhambat dan selanjutnya mukosa mulut akan menjadi lebih tipis oleh karena hilangnya keratinisasi normal, atropi, dan lebih mudah mengalami ulserasi. Anemia juga menyebabkan terjadinya kerusakan imunitas seluler, berkurangnya aktivitas bakterisidal dari lekosit polymorphonuclear, respon antibodi tidak adekuat dan abnormalitas pada jaringan epitel. Kondisi ini sering terjadi pada seseorang yang menderita defisiensi vitamin B12, folat, dan zat besi. ${ }^{2,11-14}$

Penyebab anemia yang sering terjadi adalah kekurangan zat besi. Di Amerika, kekurangan zat besi terjadi pada $11 \%$ wanita dewasa dan $3-5 \%$ pada wanita remaja, ${ }^{13}$ hanya $0,2 \%$ pria dewasa yang menderita anemia. ${ }^{12}$ Pasien memiliki riwayat sebagai mahasiswa dan bertempat tinggal 'indekos'. Pada saat pasien banyak kegiatan, seringkali makannya menjadi tidak teratur. Hal ini menyebabkan pasien mengalami penurunan asupan zat besi, vitamin dan mineral yang diduga menjadi penyebab pasien menjadi anemia. Dengan demikian didapatkan diagnosis akhir recurrent aphthous stomatitis pada pasien anemia.

Pada umumnya terapi yang diberikan pada pasien anemia karena kekurangan zat besi adalah tablet zat besi yang berisi ferrous sulfate, ferrous gluconate, dan ferrous fumarate yang diberikan peroral. ${ }^{7}$ Respon tubuh pada terapi biasanya cepat, sel darah merah akan kembali normal setelah 1 sampai 2 bulan. ${ }^{13}$ Oleh sebab itu pasien diberikan suplemen yang berisi zat besi, vitamin, dan mineral 2x1 sehari yang diminum selama 2 minggu.

Pada kontrol berikutnya, ulser pasien sembuh total, keluhan mudah lelah dan pusing hilang. Pasien dianjurkan untuk kontrol apabila sariawan timbul kembali.

Terapi yang diberikan adalah melanjutkan suplemen 1x1 sehari selama sebulan sebagai dosis maintenance. Suplemen tersebut berisi $\mathrm{Fe}$ glukonat $250 \mathrm{mg}$, mangan sulfat $0,2 \mathrm{mg}$, tembaga sulfat $0,2 \mathrm{mg}$, vitamin C $50 \mathrm{mg}$, asam folat $1 \mathrm{mg}$, vitamin B12 yang diindikasikan salah satunya untuk anemia karena kekurangan nutrisi. Suplemen tersebut berisi ferrous glukonate yang merupakan zat besi yang penting untuk metabolisme energi. Mangan sulfat dan tembaga sulfat adalah zat yang membantu membawa zat besi agar dapat diserap usus kemudian dibawa serum darah ke sirkulasi darah. Vitamin $\mathrm{C}$ berfungsi membantu zat besi agar berbentuk cair sehingga mudah diserap oleh usus. Vitamin B12 dan asam folat menjadi kofaktor yang penting untuk sintesis DNA sel darah. ${ }^{11,15}$

\section{SIMPULAN}

Dari studi kasus ini dapat disimpulkan bahwa anemia sebagai salah satu faktor pencetus timbulnya recurrent aphthous stomatitis. Diagnosis akhir ditegakkan berdasar hasil anamnesis, pemeriksaan klinis dan didukung pemeriksaan darah lengkap. Kesembuhan diperoleh setelah pemberian zat besi, vitamin, dan mineral selama 2 minggu. Untuk itu, penting bagi dokter gigi untuk mengetahui gejala klinis dan kelainan akibat anemia dalam mulut, sehingga dokter gigi dapat memberikan terapi dengan tepat.

\section{DAFTAR PUSTAKA}

1. Laskaris G. Treatment of oral disease : A concise textbook. Thieme; 2005. p. 15-7. 
2. Field A, Longman L. Tyldesley's oral medicine, $5^{\text {th }}$ Ed. Oxford; 2004. p. 154-6.

3. Cawson RA, Odell EW. Cawson's essentials of oral pathology and oral medicine, $7^{\text {th }} \mathrm{Ed}$. Churchill Livingstone; 2002. p. 294-5.

4. Wray D, Lowe D, Felix, Scully. Textbook of general and oral medicine. Churchill Livingstone; 2001. p. 225-32.

5. Greenberg G. Burket's oral medicine diagnosis and treatment, $10^{\text {th }}$ Ed. BC Decker Inc; 2003. p. 430-2.

6. Moreno, Villalpando, Shamah. Anemia. National Public Health Institute, Autonomous University of Yucatan. Mexico: Elsevier Inc; 2008. p. 174-83.

7. Ciesla B. Hematology in practice. Philadelphia: FA Davis Company; 2007. p. 66-70.

8. Neville D, Allen B. Oral and maxillofacial pathology, $2^{\text {nd }}$ Ed. WB.Saunders;2002.p.285-6.

9. Kus Harijanti, Mintarsih. Candidosis on oral lichenplanus. Dent J (Majalah Kedokteran Gigi) 2006; 39 April-June: 80-4.
10. Griffth III, Hoelein, Feddock H. First exposure internal medicine: hospital medicine, Mc Graw-Hill Companies, Inc, 2007 ; p. 3735

11. Hong-Cheng $\mathrm{Wu}, \quad$ Shin-Yu Lu. Initial diagnosis of anemia from sore mouth and improved classification of anemia by $\mathrm{MCV}$ and RDW in 30 patients. Director of Oral Medicine and Oral Diagnosis, Chang Gung Memorial Hospital. Kaohsiung Medical Center, Taiwan: Elsevier Inc, 2004; p. 679-84

12. Habbermann G. Mayo clinic internal medicine concise textbook. Mayo Clinic Scientific Press; 2008. p. 347-8

13. Silverman, Eversole, Truelove. Essentials of oral medicine. BC Decker Inc; 2001. p. 67-70

14. Beard JL. Iron biology in immune function, muscle metabolism and neuronal functioning. american society for nutritional sciences, Pennsylvania: State University; 2001. p. 4-5.

15. Hunt JR. Iron, USDA-ARS grand forks human nutrition research center, Grand Forks: Elsevier Ltd; 2005. p. 82-9. 